Perspective

\title{
Date Palm Status and Perspective in Mexico
}

\author{
Noé Ortiz-Uribe ${ }^{1}$, Ricardo Salomón-Torres ${ }^{1, * \mathbb{B}}$ and Robert Krueger ${ }^{2}$ \\ 1 Departamento de Posgrado, Universidad Estatal de Sonora, San Luis Rio Colorado, Sonora 83500, Mexico; \\ sinhuet7@hotmail.com \\ 2 USDA-ARS National Clonal Germplasm Repository for Citrus and Dates, Riverside, CA 92507, USA; \\ robert.krueger@ars.usda.gov \\ * Correspondence: ricardo.salomon@uabc.edu.mx; Tel.: (+52)-653-534-4255
}

Received: 4 January 2019; Accepted: 8 February 2019; Published: 5 March 2019

\begin{abstract}
The Date palm (Phoenix dactilifera L.) was introduced to Mexico during the Spanish colonization, but its commercial production did not develop until the second half of the past century. A literature and field research, including a trip to the oases missions and main commercial production areas, allowed us to identify the actual status for this crop in Mexico. While the date culture in the old oases is fading, in the commercial production zones it is in active development. San Luis Rio Colorado and Mexicali Valley region, comprise $97 \%$ of the commercial crop production area of the country. The main cultivar is Medjool with $94 \%$ of the growing area; actual yields are around 7.9 ton/ha. Ongoing government support and motivated growers training will lead to the application of better crop practices. It is expected to increase yields around 10 ton/ha in the next 5 years. Commercial date production is focused on exports, the internal market is growing, as well as the transformation of the product. Knowledge of the actual trends of the crop will allow to understand their historic importance and its future potential as a commodity and food. Production practices, competitive advantages and research results are presented.
\end{abstract}

Keywords: Date palm; Phoenix dactylifera L.; Medjool; San Luis Rio Colorado; Mexicali; Dates; Mexico

\section{Introduction}

The exact origin of the date palm (Phoenix dactylifera L.) is unknown, but it is believed that this plant could have been domesticated in the southern region of present-day Iraq at least 6000 years ago, according to archaeological evidence from ancient Mesopotamia [1-3]. This plant has been cultivated by many cultures, such as the Sumerians, Assyrians, Babylonians, and later cultures in Western Asia. Later, its cultivation was extended to all of North Africa, southern Central Asia, and southern Europe, eventually reaching America through the Spanish conquest [2-4].

The date palm in Mexico has two different historic routes, the first one being the introduction of the palm to Mexico by the Spaniards during the colonization process after the conquest [5]. The native palm oases of Baja California were the sites where the date palms grew best, but yields and fruit quality were poor, and the crop culture in these areas is fading. The other route came about in the 20th century, when high quality cultivars were introduced to the San Luis Rio Colorado-Mexicali valley, where the appropriate climate, rich soils, and modern agricultural practices allow good yields of high quality fruit, mainly the "Medjool" cultivar [6,7].

The date industry in Mexico is very small compared to the major date-producing countries, such as Egypt, Iran, and Algeria [8]. However, its production has increased by $600 \%$ over the past 35 years. According to FAO data, Mexico produced 8,215 tons in 2017, which ranks it as the 27th largest producer of dates in the world [8]. Likewise, the Mexican companies that produce dates are well organized. Each year they improve their cultivation techniques, gain more experience to obtain 
better yields, and continue the expansion of the planted areas [9]. Large and small date growers in Mexico are organized in associations called: "Sistema Producto Dátil", to improve the competitiveness of the crop with better cultural and commercial practices, as well as negotiating with the government programs aimed at supporting the production.

Within the support granted by FAO for the development of date cultivation around the world, its team of consultants made a technical support visit to project TCP/MEX/3102 "Promotion of the production and improvement of dates", which was initiated for Mexico in 2008 [10]. Its officers visited the date plantations in Sonora, Baja California, and Baja California Sur States. They also evaluated possible sites for cultivation in the States of San Luis Potosí and Sinaloa, but it was determined that there were not agroclimatic conditions suited for the cultivation of the date, nor the local experience, nor the familiarity with the crop in these States. Therefore, it was decided to support the plantations already established in Sonora and Baja California. Plantlets propagated in vitro were brought to the valley of Santo Domingo in Baja California Sur and were planted, and producers from Baja California were supported in post-harvest and processing projects [11].

Currently the regions where dates are commercially produced continue to expand, with 924 hectares planted that entered production in 2017 [12], and other possible sites where the crop could potentially be cultivated are being analyzed, as in Ciudad Delicias in the State of Chihuahua and the valley of the Yaqui in the State of Sonora.

In Mexico there is not a culture of date consumption, but the internal market is growing due its health benefits, nutritional value and diversification of the presentations that are available to the consumer. Dates are transformed and offered, mixed or covered with chocolate, peanut butter, nuts, or chili pepper. Also, it is processed into wine, beer, dressings, juice, bread, and cake, and is an ingredient for gourmet dishes in haute cuisine.

This perspective is a summary of the status of modern date palm cultivation, including its propagation, utilization, description, management, and socioeconomic importance, since its introduction to Mexico at the end of the 1960s.

\section{Historical and Current Agricultural Aspect}

\subsection{The Cultivation of the Date Palm in Mexico}

A superior area has been identified for the cultivation of dates at the commercial level, this being within a geographical belt between the coordinates $24^{\circ} \mathrm{N}$ and $34^{\circ} \mathrm{N}$ [1]. Within this geographic area are the majority of the top 10 largest producers of date in the world, which according to data from the United Nations Organization for Food and Agriculture (FAO) in 2017 were: Egypt, Iran, Algeria, Saudi Arabia, Iraq, Pakistan, United Arab Emirates, Sudan, Oman, and Tunisia. These countries produced $7,267,316$ tons of dates, which represent the production of $88.9 \%$ of total world production. In contrast, the production of dates in America and Europe was $0.58 \%$ and $0.18 \%$, respectively, of the global production for the same year [8].

The cultivation of the date palm was introduced to the central part of Mexico in the mid-sixteenth century by the Spanish colonizers [5]. However, due to climatic factors, that area of Mexico was not suitable for the production of dates [13]. The Jesuit missionaries in their period of evangelism established settlements known as missions in 15 places on the Baja California Peninsula, chiefly in areas belonging to the present State of Baja California Sur, where dates can reach maturity, producing a viable crop in these areas. During the colonization process, which lasted from the late sixteenth to the mid-seventeenth centuries, various date palm plantations were established in oases areas, and some of them have survived to this day [14]. The oases, which supported the native Washingtonia spp fan palms, were suitable for date production not only due to the climate, but also to the presence of high levels of soil water. Both Washingtonia palms and date palms require high amounts of soil moisture for vigorous growth and, in the case of the date palm, acceptable fruit growth [1]. 
After the Spanish colonial period, the oases continued to have a large agricultural heritage, including the date plantations, due to the availability of water in the arid Baja California peninsula [15]. There are records detailing date production in the largest oases of up to 200 tons in 1957, as well as the export of dates from this region of Mexico to China [14]. However, date production was losing relevance, due to the fact that the dates were considered criollo types. In this context, criollo refers to unimproved dates descended from the original importations of the Spanish; they are of low quality and value, propagated mostly from open pollinated seeds rather than from offshoots of superior selections.

Modern date cultivation in Mexico arose independently from the traditional oases date culture. By the end of the 1960s, date cultivation was established in the San Luis Rio Colorado valley in the State of Sonora using offshoots imported from Yuma, Arizona, U.S.A. [16]. The 'Medjool' cultivar is the main commercial date grown in Mexico (94\%), followed by small plantations of the cultivars 'Deglet Noor' $(5 \%)$, and others such as 'Khadrawy', 'Zahidi', 'Barhee, 'Honey', 'Hallawy', and criollo dates (1\%). The 'Medjool' cultivar is originally from Morocco [17], and it is one of the most esteemed in the world. It has a large fruit body and soft texture, which makes it highly appreciated [18]. The cultivar 'Medjool' arrived in America in 1927, when it was introduced to Southern California in the United States [16]. Decades later it was brought to Mexico, and became established as the main cultivated variety there. The criollo dates grown in Mexican oases are small and hard, containing little pulp and having large seeds. Nowadays, most of these plantations are not cared for, and the culture of the date crop in the oases of Baja California is being lost. In addition to the abandoning of these plantations, forest fires are destroying a large number of adult palms.

In contrast, a modern date crop industry mainly for export is thriving in the valleys of San Luis Rio Colorado and Mexicali, in the States of Sonora and Baja California, respectively, and is extending to other areas such as Altar and Caborca in Sonora, the Ejido Alfredo V. Bonfil in Baja California Sur, and Ejido Bilbao and Viesca, in Coahuila State (Figure 1).

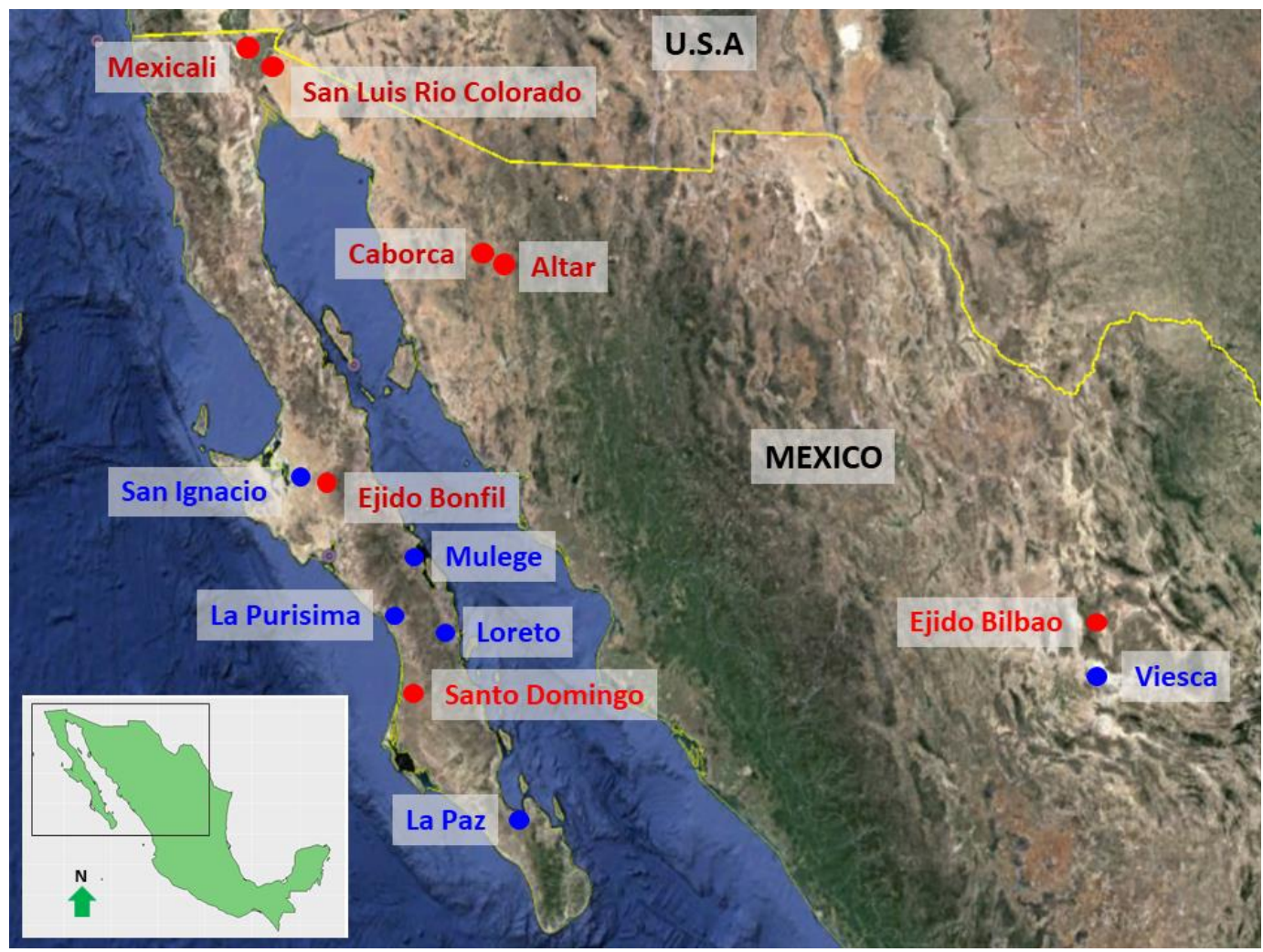

Figure 1. Areas in red, grow high-value commercial cultivars. Areas in blue, cultivate criollo dates. 
The date palm is also used as an ornamental plant. There are two big nurseries focused on this kind of use. They use seed propagated plants. One is located in Hermosillo, Son., and another in Mexicali, B.C. Mature date palms are sometimes sold for use as ornamental trees.

\subsection{Production Statistics and Economics}

The size of the date crop is increasing rapidly in Mexico (Figure 2). In 2016, the production was 8085 ton, obtained from a harvested area of 1183 ha, whereas in 2017, the production was 8215 ton from a harvested area of 1377 ha, with a value of 22,650,371 USD. The total planted area (bearing and non-bearing) increased as well, from 2110 ha in 2016, to 2366 ha in 2017, an increase of 256 ha entering production [12] (Table 1). For 2018, a total of 924 ha are reported to be entering production.

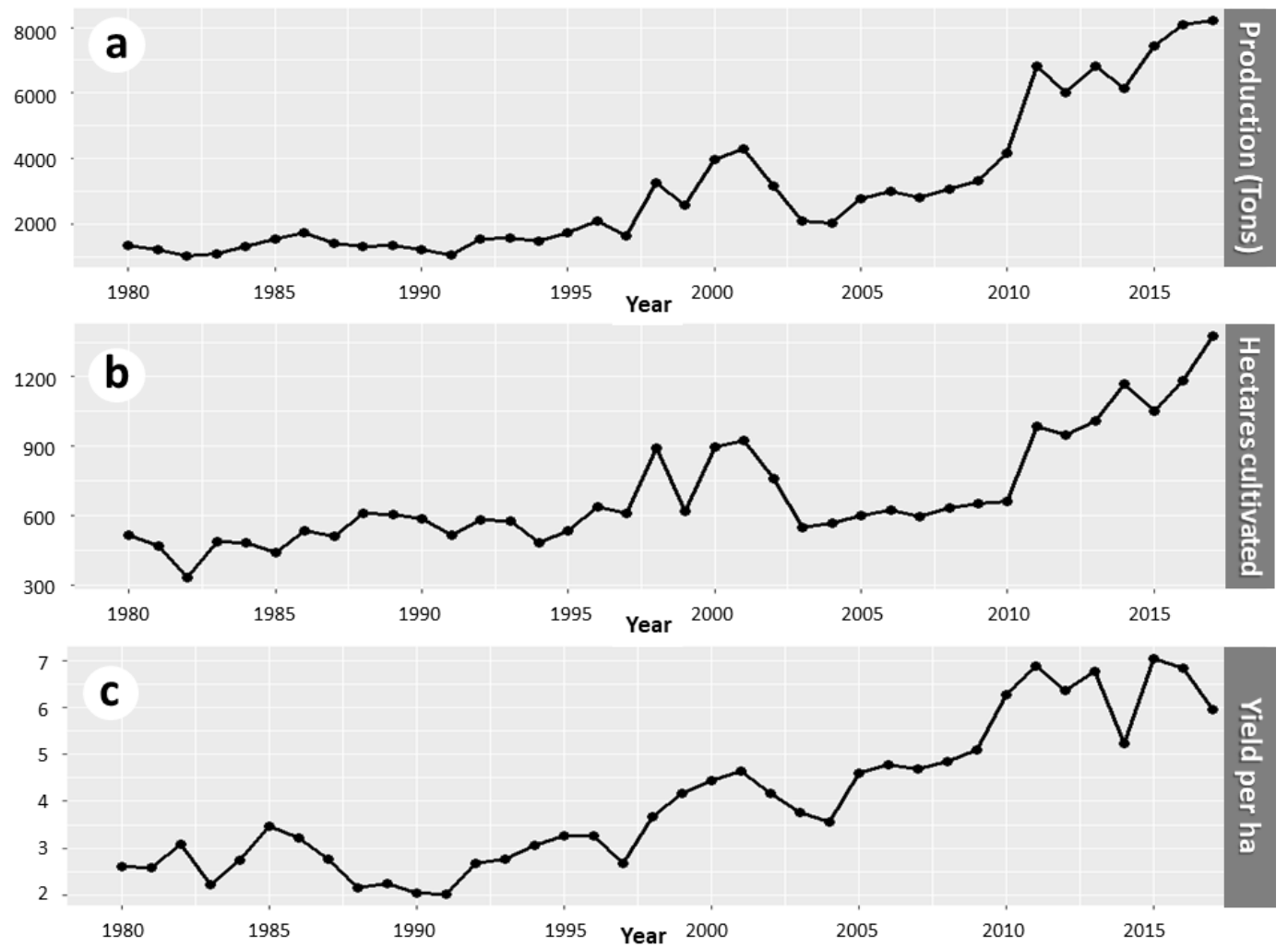

Figure 2. Representation of production in Mexico from 1980 to 2017. (a) Production in tons. (b) Area cultivated in hectares. (c) Corresponding yield per hectare.

The Agriculture Ministry of Mexico recognized the date as a high priority crop in 2015. Mexico has become the second largest producer of dates in America, following the United States, which is the main date producer on the American continent [8]. The largest production area of the date cultivar 'Medjool' in Mexico is located in the Valleys of San Luis Rio Colorado and Mexicali in the States of Sonora and Baja California, respectively, achieving between both areas $97 \%$ of the total date production in the country in all date cultivars [12]. Although the 'Medjool' cultivar is native to Morocco [17], the largest production of this variety is found in Israel, California, and Arizona in the United States, and Mexico $[8,19]$. 
Table 1. Statistical and economic summary of date production in commercial plantations of Mexico in the period from 2014 to 2017.

\begin{tabular}{|c|c|c|c|c|c|c|}
\hline Producer States & Year & $\begin{array}{c}\text { Surface } \\
\text { Planted (ha) }\end{array}$ & $\begin{array}{c}\text { Harvested } \\
\text { Surface (ha) }\end{array}$ & Production (ton) & Yield (ton) & $\begin{array}{l}\text { Production Value } \\
\text { (Millions USD) }\end{array}$ \\
\hline \multirow{4}{*}{ Baja California } & 2014 & 444.50 & 271.50 & 1822.26 & 6.71 & 3.87 \\
\hline & 2015 & 668.25 & 303.00 & 2411.84 & 7.96 & 7.33 \\
\hline & 2016 & 841.22 & 346.00 & 3394.07 & 9.81 & 10.56 \\
\hline & 2017 & 805.25 & 346.00 & 3388.92 & 9.79 & 11.12 \\
\hline \multirow{4}{*}{ Baja California Sur } & 2014 & 345.00 & 285.00 & 50.70 & 0.18 & 0.12 \\
\hline & 2015 & 348.00 & 135.50 & 157.26 & 1.16 & 0.32 \\
\hline & 2016 & 332.50 & 235.00 & 154.00 & 0.66 & 0.25 \\
\hline & 2017 & 335.00 & 278.00 & 302.65 & 1.08 & 0.72 \\
\hline \multirow{4}{*}{ Coahuila } & 2014 & 15.00 & 5.00 & 11.50 & 2.30 & 0.02 \\
\hline & 2015 & 15.00 & 5.00 & 12.60 & 2.52 & 0.03 \\
\hline & 2016 & 15.00 & 0.00 & 0.00 & 0.00 & 0.00 \\
\hline & 2017 & 15.00 & 5.00 & 7.75 & 1.55 & 0.02 \\
\hline \multirow{4}{*}{ Sonora } & 2014 & 907.00 & 607.00 & 4240.60 & 6.99 & 6.68 \\
\hline & 2015 & 909.00 & 609.00 & 4845.40 & 7.96 & 9.47 \\
\hline & 2016 & 922.00 & 602.00 & 4537.50 & 7.54 & 10.12 \\
\hline & 2017 & 1211.00 & 748.00 & 4516.00 & 6.04 & 9.57 \\
\hline
\end{tabular}

\subsection{Research in Date Palm}

Because commercial date palm cultivation is of recent introduction in Mexico, cropping practices developed in the United States have been adjusted to Mexican environmental and economic conditions, rendering so far an excellent performance from the crop. The main research efforts are carried by the "Campo Agrícola Experimental de Mexicali", belonging to the "Instituto Nacional de Investigaciones Agrícolas, Pecuarias y Forestales" (INIFAP) [20], and focus on transplanting techniques, irrigation techniques, and plant fertilization. This research center additionally has a strong educational program for new date growers. In Sonora State, the research on date palm is carried by a team of researchers from Sonora State University at the San Luis Rio Colorado Campus [21]. The research team is focused on pollination, bunch management, biochemistry of the date, physiotechnology, and genetics.

The Institute of Agricultural Sciences (ICA) from Autonomous University of Baja California (UABC) [21] is starting research efforts as well, and recently has established a small date palm experimental field $\left(32^{\circ} 29^{\prime} 37^{\prime \prime} \mathrm{N}, 115^{\circ} 12^{\prime} 46^{\prime \prime} \mathrm{W}\right)$, located in the ejido "El Peligro", in the Mexicali valley, B.C. This small field was established only with 'Medjool' palms, for educational and research purposes for undergraduate and graduate students. An in vitro propagation project is ongoing.

A study of the genetic diversity of the date palms in Mexico is in development. Efforts are being made to genetically characterize the populations of date palm, including the old populations introduced to the oases, as well as the modern productive varieties. Molecular markers are being studied to define the genetic structure of the population. The molecular markers known as microsatellites or Single Sequence Repeats (SSR) are a useful tool to identify markers associated with fruit quality, production and disease resistance, and will be applied in a program to improve the productivity of the date palm [22].

\subsection{Current Agricultural Problems}

\subsubsection{Pests, Rodents and Birds}

Pest presence on date palms in Mexico is not significant, but there are various potential threats. Insect pests, such as various species of nitidulid beetles, have been detected infesting Medjool dates in the Mexicali valley; adult colonies of Haptoncus luteolus (Erichson) can be found in the racemes during the harvest period. Carpophilus dimidiatus (Fabricius) and C. hemipterus (Linnaeus) larvae are found inside the harvested date fruits. Larvae of Phyllophaga spp (May bettles) feed on the plant root affecting the establishment of new plantations. Red mites (Tetranychus spp) can affect the racemes 
leading to total loss of the fruits. No research has been done to characterize the incidence of these pests in the region.

There are various potential pests that are being monitored by plant health committees (Comité Estatal de Sanidad Vegetal), and road checkpoints actively control interstate plant movement in order to avoid the entrance to Sonora and Baja California States of the palm red mite (Raoiella indica) and red palm weevil (Rhynchophorus ferrugineus). An additional treat to the main production areas is the South American palm weevil, (R. palmarum). This species has many host species, and it has been detected in cities close to the production areas; therefore, a program for attending its future presence needs to be addressed [23].

A possible risk has been detected in cities close to the date production areas with growing populations of monk parakeet (Myiopsitta monachus). This bird makes its nests on the palm and feeds of the dates. Populations have been observed in Hermosillo, Sonora, in garden palms (Figure 3a,c). This pest has been reported in the city of La Paz, Baja California Sur, close to the oases plantations [24]. Numbers of the monk parakeet are also increasing in the city of Mexicali, from where they can easily move and infest the neighboring production areas.
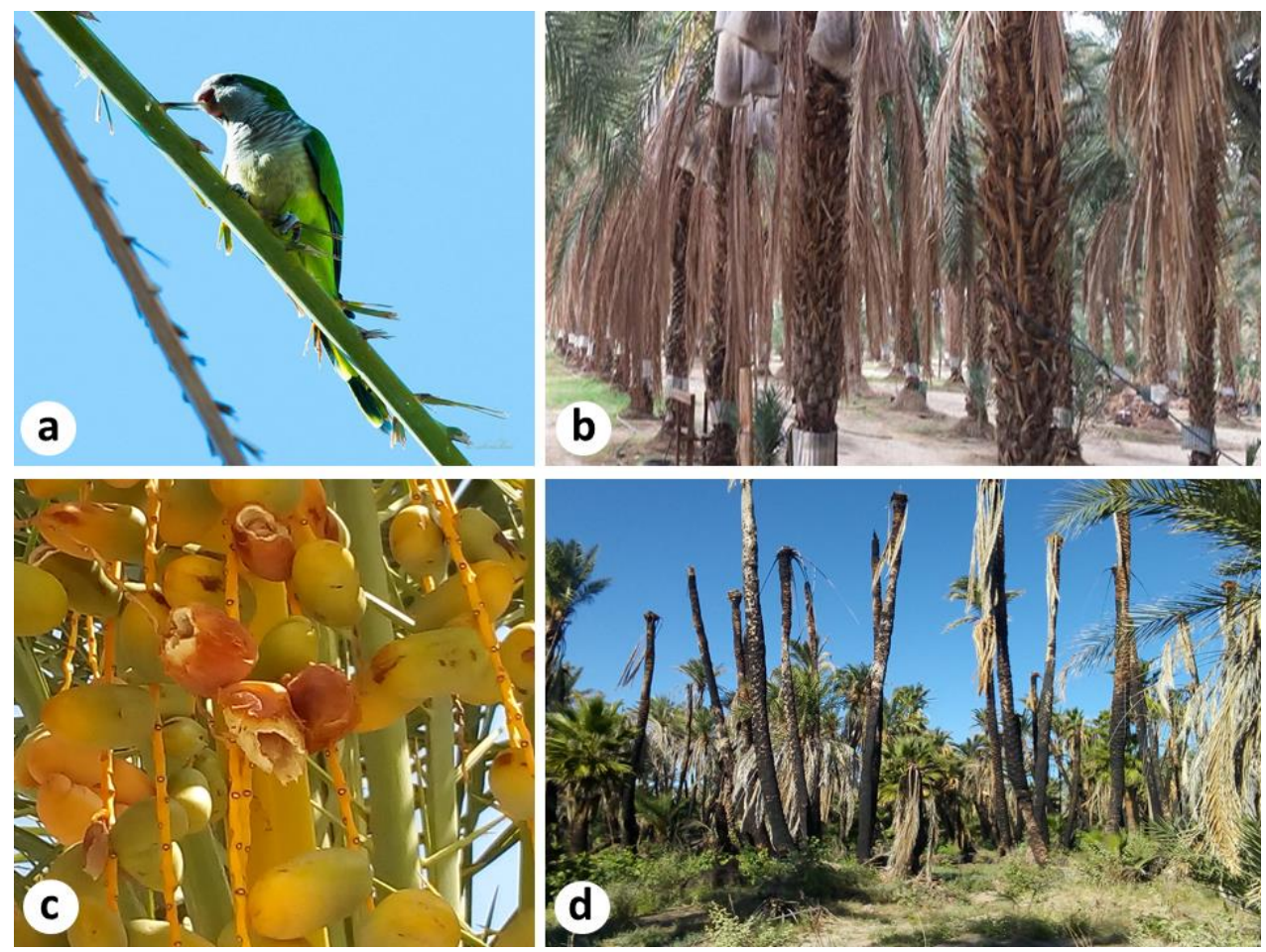

Figure 3. Current agricultural problems. (a) Monk parakeet devouring a date palm branch in Hermosillo, Sonora. (b) Sheet cover at the base of the trunk of the palm, to prevent the climbing of small rodents, in Laguna Salada, Baja California. (c) Bird damage to date fruit. (d) Remains of burned palm trees by natural fire in the oases of San Ignacio, Baja California Sur.

The only mammals that affect date palm are the round-tailed ground squirrel (Xerospermophilus tereticaudus) and gophers (Thomomys bottae). The ground squirrels climb the palms and eat the date fruit at any developmental stage. In the Laguna Salada $\left(32^{\circ} 10^{\prime} 43^{\prime \prime} \mathrm{N}\right.$, $\left.115^{\circ} 40^{\prime} 41^{\prime \prime} \mathrm{W}\right)$, in the Baja California growing area, the farmers developed a method to control the damage, using steel plates nailed to the plant trunk to prevent the climbing of the squirrel (Figure 3b); regarding gophers, they eat the plant roots and damage the irrigation systems. Control is made with wire-type body gripping traps.

Date palm diseases in commercial production areas are not reported yet, but some plantations in both San Luis Rio Colorado and Mexicali regions, show a few numbers of plants with symptoms 
similar to those of Fusarium. Since this disease can be devastating to date palms, these palms need to be closely monitored. Additional information regarding potential disease problems needs to be developed for the Mexican date-producing areas.

\subsubsection{Water Availability}

The Colorado River provides the water which is used in the date-growing areas in the Mexicali and San Luis Colorado valleys. Its provision is highly controlled and nowadays it is more common that the water rights are retired from agricultural use and transferred to industrial use. For example, there is a conflict in the Mexicali valley between farmers and a beer company which requires 20 million cubic meters of water per year for its operation $[25,26]$. The Colorado River also supplies water to seven states in the United States. Water allocation to the U.S. and Mexico is regulated by various compacts and agreements between the U.S. states and between the U.S. and Mexico [27]. Reduced amounts of Colorado River flow and drought conditions may well result in less Colorado River water being available both in the U.S. and in Mexico.

The water problem is common in other areas as well, for example, in Caborca and Altar, Sonora, the ground water level is too deep. In Viesca and Bilbao, Coahuila, the milk industry competes strongly for the water. However, in Ejido Alfredo V. Bonfil $\left(27^{\circ} 20^{\prime} 26^{\prime \prime} \mathrm{N}, 112^{\circ} 46^{\prime} 47^{\prime \prime} \mathrm{W}\right)$, in Baja California Sur, the water availability is sufficient to allow for the increase in the growing area.

\subsubsection{Environment Risks}

Forest fires are a common problem among the oases's plantations. The hot summers increase the risk of fires in the mostly unattended plantations of the oases. Unattended date palms and Washingtonia palms usually have large amounts of dry leaves, making them susceptible to fire hazards. Often the palms are not completely killed by fires but crops are lost and it takes several years to recover. Recent fires have affected the plantations in San Ignacio (Figure 3d) and Mulege, in Baja California Sur. The Baja California Sur State is highly susceptible to hurricanes and continuous rains in the seasons of date maturation and harvest, causing the falling of the adult palms, and the remaining high humidity favors the fungi attack and fermentation of the fruits. In addition, hurricanes sometimes cause salt water intrusion into fresh water estuaries near the coast. Although date palms and Washingtonia palms are relatively salt tolerant, these salt water intrusions may result in soil salt levels high enough to weaken or kill palms growing near the coast. This is mostly a problem in the oases's cultures, particularly Mulegé. In the valleys of Mexicali and San Luis Rio Colorado, rains are very scarce in the ripening and harvest seasons of the fruit and so do not present problems.

\section{Crop Practices in Commercial Plantations}

The crop practices used in commercial date production in Mexico are mostly the same as those used in the United States, since the main growing areas in the U.S. are close to the San Luis-Mexicali Valley, where $97 \%$ of the Mexican dates are grown and have similar climates and soils [12]. Some companies have plantations in both countries, and most of the U.S. plantation workers are Mexicans or of Mexican national origin.

\subsection{Fertilization and Irrigation}

Fertilization is provided mainly for N-P-K, at rates between 2 and $2.5 \mathrm{~kg}$ of nitrogen, $0.5 \mathrm{~kg}$ of phosphorus, and $6 \mathrm{~kg}$ of potassium for an adult plant per year. In sandy soils, fertilizer is delivered via irrigation systems, and amendments for improving soil water retention are widely used. Organic production areas are small, but slowly increasing. Various farms are being certified since the market of this category of products gives better prices for the organically grown date.

Plantation practices differ based on the irrigation technique. Limited water supply is forcing irrigation to turn to pressurized systems; however, flood irrigation is the main method of water delivery. Flood-irrigated fields are leveled with laser equipment, whereas in sandy desert areas, 
where flood irrigation is impractical, no leveling is required, and the use of drip irrigation with pressure-compensated drippers allows small slopes and dunes in the production field. In Baja California Sur, irrigation in modern commercial plantations is delivered by dripping systems, whereas in Coahuila, only the flooding technique is used.

\subsection{Plant Propagation}

Propagation is mostly from offshoots (Figure 4a), and up to now, very few growers in Mexico have used tissue culture-produced plants. The most widely-planted cultivar, 'Medjool', produces abundant offshoots. In vitro propagated plants are slowly being introduced to the region, overcoming the distrust of the growers to the possible somaclonal variability of plants obtained with this technology. In vitro plants developed in the US and Qatar have been planted in recent years in the Mexicali valley. Data of the performance in the field is expected in the near future. Offshoots of 7 to $15 \mathrm{~kg}$ are preferred for propagation, since they have the fastest establishment rate. Contrary to other reports [28], the best method for a successful transplant is eliminating all roots in the offshoot, since they will rot, and there is a high risk that the rotting gets into the shoot.

The use of rooting agents such as alpha naphtil acetamide and indole3-butyric acid increases the rate of survival of the new plant, as well as promoting plant growth [29]. The leaves of the offshoots are trimmed to a meter in length, then covered with jute or sisal burlap and tied for protection of the new leaves that will emerge in 3-4 months, once the plant is established. Offshoot survival varies greatly depending on good management of the material, a short time between extraction and planting, and soil type. Plantation in heavy soils requires careful planning and processing, since the average mortality is $35 \%$ and may reach over $70 \%$. The main problems observed affecting the survival of the new plants are poor offshoot quality, mismanagement of the offshoots, and saline and heavy soils. Survival of new plantations in heavy soils is improved by digging a bigger hole, and putting a layer of sand between the offshoot and the soil to give better rooting conditions. The most used tree spacing is $8 \times 8 \mathrm{~m}$. 


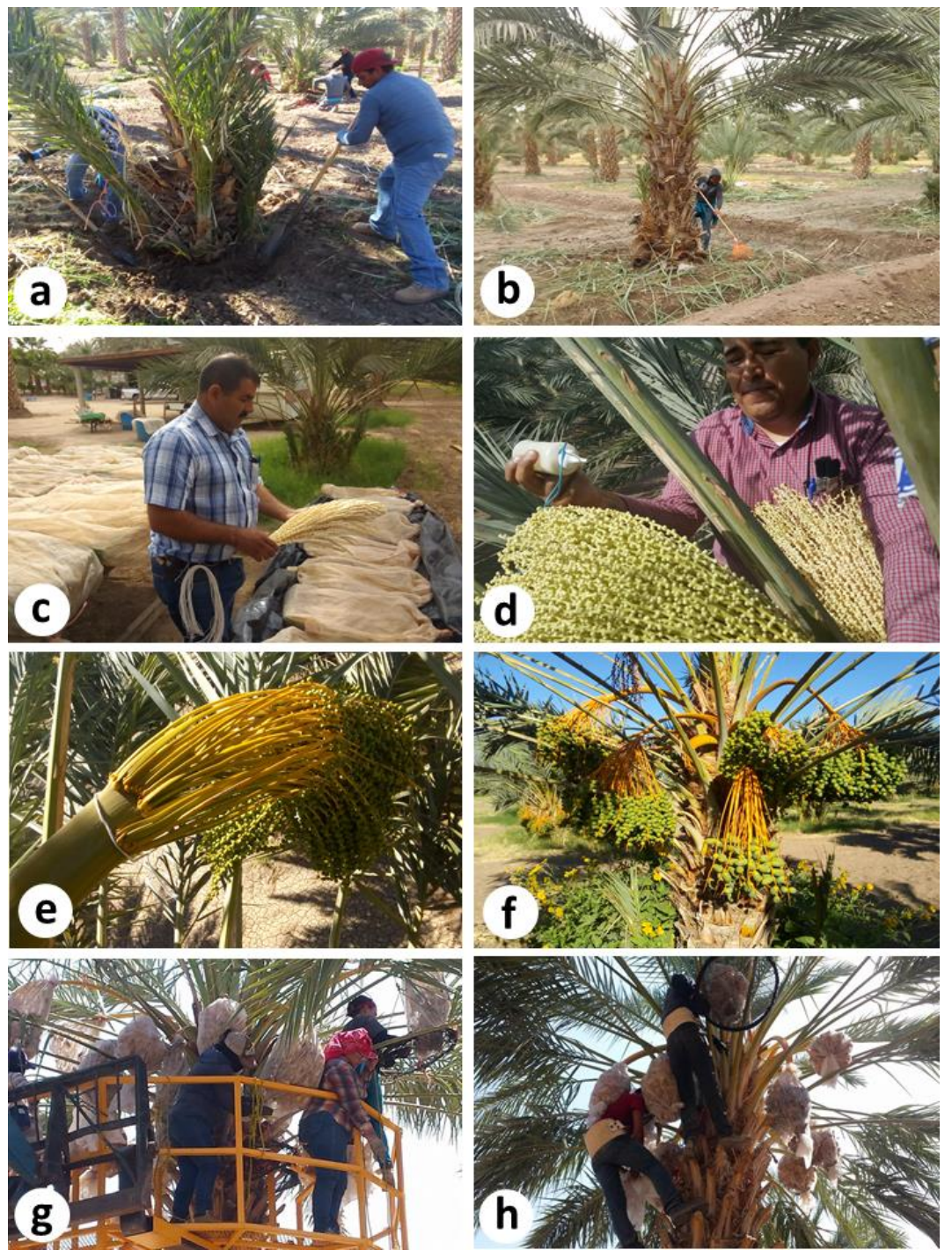

Figure 4. Cultural practices. (a) Removal of palm offshoots. (b) Elimination of thorns and leaves in the palm. (c) Drying male spathes for pollen extraction. (d) Pollination process. (e) Spathe 2 months after pollination. (f) Young palm with fruit of various sizes. (g) Women working on the harvest of the date on board a mechanical basket. (h) Traditional method of harvesting dates.

\subsection{Pollination and Bunch Management}

The process of pollination in commercial plantations is carried out artificially (Figure 4c,d), while in oases it is performed naturally by the wind. Pollination takes place once the inflorescence is open by late February or early March. Pollen from male plants is collected when their flowers are open or the spathe starts to dehisce. Inflorescences are cut and taken to a storage room, the spathes are removed, and the flowers hung over paper. As the flowers dry, the pollen is released, usually with aid from some shaking of the inflorescence. The pollen is collected and can be stored under refrigeration from one season to the next. For pollen application to the female inflorescence, the spathes are removed, and the spikes are tied with a slipknot to keep the raceme compact. Squeeze bottles are used to spray the female inflorescence with a mix of 30 to $50 \%$ of pollen and wheat flour. Since inflorescences appear sequentially, starting with the upper part of the crown, it is necessary to give three pollen applications at 6-day intervals. A method consisting of putting male flower stems inside the female inflorescence is in use in few plantations $[1,2,27]$. 
Thinning of the bunch follows pollination and includes removing the center of the bunch and thinning of the strands. Some 15 to 20 flowering strands are cut from the center of the inflorescence; this practice is performed in April. In the latter, some developing fruits are removed from the strands (Figure 4e,f). Fruits are removed so that there is a separation of 1 inch between remaining ones, preferably the fruits being oriented on opposite sides of the strand. This is to prevent the fruit from contacting each other, to provide room for growth, and to reduce the number of sinks in order to increase fruit size. From 12 to 18 fruits per spikelet are left. This practice improves fruit quality and reduces alternate bearing. It is performed on the 'Medjool' cultivar, and takes place by early May, when fruits are approximately 1 centimeter long. Another thinning activity can be applied when the number of racemes in the plant are over 20. A concurrent activity to the thinning process consists of the tying of the bunch to the closest leaf in a position for easy access during the following activities [30]. This supports the bunch and reduces the number of broken fruit stalks.

Protection of the bunch is a must to obtain high quality fruit. Sacs of mesh fabric are placed covering the fruit raceme to avoid damage from birds and insects. This activity is carried out when the fruits turn to a yellow color at the khalal stage in July to August.

Older leaves are pruned and the residues are chopped and incorporated into the soil or burned (Figure $4 \mathrm{~b}$ ). Since the date palm is a recently introduced crop, there is no culture of use for the crop residues, such as the pruned leaves, dates from raceme thinning, and the portion of the raceme remaining after harvest. Dethorning and removal of the portion of the raceme remaining from the previous season are carried out at the same time as pruning. This practice allows safe work around the inflorescences, and takes place in November or December.

\subsection{Harvest}

The maturation of 'Medjool' dates takes place gradually from late August to early October. In young palms, dates are harvested from the ground. As the plant gets taller, the workers climb using the strong leaf bases that remain after pruning. Once they reach the crown part of the plant, they secure themselves with a harness, then shake the raceme and open the lower part of the sack to collect the dates, then the sack is retired until the last harvest pass. Dates are collected into a circular tray, made with a metal ring and fishing net, then the tray is lowered to the ground where the dates are put in 2-inch-deep plastic trays. For taller trees, a forklift with a round platform is used to elevate six to eight workers to the raceme level, where they collect the fruit [30] (Figure 4g,h).

\section{Status of the Crop in Baja California Sur}

Historic references about the introduction and production in the oases of Baja California can be found elsewhere [5,13-15]. We made a trip to the missions of Baja California to find the current status of date palm crop production. Old residents of oases plantations were interviewed using a non-structured survey. In the southern part of Baja California Sur, around the city of Todos Santos $\left(23^{\circ} 26^{\prime} 47^{\prime \prime} \mathrm{N}, 110^{\circ} 13^{\prime} 35^{\prime \prime}\right)$, no commercial crop of date palm was found. There are old houses with yards showing a few palms, and many places have palms as ornamentals in this highly prized touristic destination. Near the city of La Paz, 22 ha have been reported [12]. The Loreto Mission $\left(26^{\circ} 00^{\prime} 44^{\prime \prime} \mathrm{N}\right.$, $111^{\circ} 20^{\prime} 34^{\prime \prime} \mathrm{W}$ ) was the administrative center of the Californias during the Jesuit period, however, today it is a touristic destination. Here, date palms are ubiquitous in gardens, streets and parks, but no commercial cultivation was detected. The oases of Santa Rosalía de Mulegé $\left(26^{\circ} 53^{\prime} 26^{\prime \prime} \mathrm{N}\right.$, $111^{\circ} 58^{\prime} 52^{\prime \prime} \mathrm{W}$ ) has a large area with palms. The date palm was one the most important crops in these oases, exporting to China and Mexico's mainland from the late 18th century to the late 20th century. Today, commercial production is vanishing due to various factors, such as the low productivity and quality of the old plants that dominate the plantations, as well the lack of agronomic management, such as artificial pollination, fertilization, and bunch management. In addition, a loss of interest was observed in the new generations of farmers, who prefer to develop more profitable economic activities such as fishing or migrate to find employment in large cities. Likewise, the older generations cannot 
afford the risk of climbing the old tall palms to obtain a harvest of quality and price. Another factor affecting the reduction of date production is the current economic and cultural development of the region, where an increase in diversity of food and occupational options is taking place as the communication systems increase their impacts on the people and oases landscapes [15].

The San Ignacio Mission $\left(27^{\circ} 17^{\prime} 01^{\prime \prime} \mathrm{N}, 112^{\circ} 53^{\prime} 54^{\prime \prime} \mathrm{W}\right)$ was one of the most important date growing oases in Baja California Sur. In the late 20th century, date production was an important activity, the fruit being sent to Mexico City and Guadalajara, where it was sold as "California Date". The culture around date production and consumption was rich; there were diverse forms of use in bread-making, local candy versions, hot beverages, liquor distillation, etcetera. A project for construction of a packing house was proposed, but the price of the dates was low, and it did not advance further. Today, oases date production is in a crisis. The lack of technical management of plantations, the burning of the plants by fires, and the low fruit quality of the dates have resulted in dwindling production. The active sale of adult palms for use as ornaments in the gardens of tourist places in the south of the state was noted.

The Ejido Alfredo V. Bonfil $\left(27^{\circ} 20^{\prime} 26^{\prime \prime} \mathrm{N}, 112^{\circ} 46^{\prime} 47^{\prime \prime} \mathrm{W}\right)$ date palm plantations were established in 1981, as part of a government program carried out by the disappeared "Comisión Nacional de Fruticultura" (CONAFRUT). There are 50 hectares of 'Medjool', 'Deglet Noor' and 'Khadrawy' cultivars. Offshoots were brought from Indio, California in the U.S.A. to establish this plantation [14]. The production here uses a good level of technical management, including drip irrigation, fertilization, thinning, weed management, etc. They use the pollination technique of putting male flower branches in the female flower. Fruit yields are in the range of 6 to 8 ton/ha. Interestingly, the production of this area is directed to the local market in the south of the state. The planted area is in the process of being doubled.

In the Santo Domingo valley $\left(25^{\circ} 21^{\prime} 09^{\prime \prime} \mathrm{N}, 111^{\circ} 59^{\prime} 20^{\prime \prime} \mathrm{W}\right)$, a plantation was established with the support of FAO. The plants were brought from the Middle East, and obtained in vitro from the 'Khalas', 'Barhee', 'Unamed Taj', 'Medjool', and other cultivars. Some of these palms started producing fruit in the season of 2018. From the same project, additional stock was donated to the Autonomous University of Baja California Sur (UABCS) [31], and they use the plants for educational purposes.

Other places produce certain criollo date types with red colors during the growing stages, turning purple at maturity, such as La Purisima $\left(26^{\circ} 11^{\prime} 08^{\prime \prime} \mathrm{N}, 112^{\circ} 04^{\prime} 33^{\prime \prime} \mathrm{W}\right)$ [14].

Finally, the Mexican government is looking to increase the date palm growing area in Baja California Sur, through various programs of technical and economic assistance.

\section{Production and Commercialization.}

\subsection{Fruit Quality Characteristics.}

Regarding commercial fruit quality, skin separation and length of the fruit define the quality of the 'Medjool' date. Length classification parameters are as follows: small ( $<1.5$ in), medium (1.5-2 in), large (2-2.25 in), and jumbo (>2.25 in). Skin separation between 0 and $10 \%$ in any of these classifications is acceptable.

In a study on the effect of pollinators on the recipient female 'Medjool' in Mexico, the raw data reported its fruit length in a range of 1.81-2.20 in an experiment where 12 racemes were left per palm, 50 threads per raceme, and 12 dates per thread [7]. Likewise, in another study conducted in Mexico [6], the chemical composition of 'Medjool' dates was reported with the following parameters: composition proximal (g/100 g, dry weight), moisture (17.14-27.38\%), protein (2.92-3.47), lipids (0.68-0.80), fiber (6.86-7.29), ash (2.36-2.82). Sugar content $(\mathrm{g} / 100 \mathrm{~g}$ dry weight), total sugars (40.04-77.78), reducing sugars (63.41-73.38), non-reducing sugars (4.40-6.64), sucrose (4.18-6.31), glucose (33.60-38.75), and fructose (29.80-35.08). Mineral content (mg/100g, dry weight), Potassium (794.30-869), magnesium (132.10-150.10), calcium (105.23-131.73), phosphorus (105.4-145.70), iron (0.348-0.763), manganese (0.175-727), and zinc (0.084-0.614). 
These quality characteristics are similar to or better than those reported in similar studies in Jordan, Iran, Morocco, and India [18,32-35]. So we can conclude that the date cultivar 'Medjool' cultivated in Mexico is of high quality.

\subsection{Harvest and Postharvest.}

Date yields are improving over time. In Figure 2, it is shown that on average for the year 2005 the yield was below 5 tons per ha, while for 2015 it was up to 7 tons, including all cultivars. The most recent reports from SIAP [12], for the year 2017, show that in the San Luis and Mexicali valleys, the average yield was 7.9 ton/ha for the elite cultivars, and for criollo dates in other areas, 1.3 ton/ha.

In the commercial production areas, once harvested, dates are transported to packing houses, where they are selected, fumigated, and frozen. Some growers do not dry the product since the quality physical characteristics of the 'Medjool' date are lost when are rehydrated. Big farms have their own cold storage rooms and packing installations. As the product batches are sold, they are rehydrated and packaged according to the customer's requirements. Fresh date presentations for the retail market are diverse, the most standard presentations being boxes from 1 to $5 \mathrm{~kg}$. From there, a myriad of diverse containers such as cardboxes, baskets, plastic jars, etc. are used to present dates in the retail market.

Most of the small and medium growers sell the raw production to a packing house, where the fruit is selected at standard sizes and exported. Other growers sell the product to local markets. In the most recent seasons, packing house capacity has been insufficient to manage the increased production.

Commercial date production in Mexico is aimed at the export market. The regional 'Medjool' price is set in Los Angeles, California, wholesale produce market, and is estimated to grow at an annual rate of $3.5 \%$ between 2016 to 2020 [36]. An average of $56.6 \%$ of dates produced in Mexico are of exportable quality [36]. Mexican date exports were valued at 3.8 million USD in 2013 and 8.4 in 2017, increasing by $122 \%$ [12,36]. The product has been sold to USA, Australia, UK, France, China, and Germany. The same quality product is starting to being sold in high-end stores in the main cities of Mexico. The Mexican government is strongly promoting the commercialization of the dates in the country, throughout agrifood business meetings, State fairs, and digital campaigns. In contrast, date imports into Mexico are low, although some high-end stores sell fresh presentations of varieties such as 'Khadrawy' and 'Deglet Noor'.

\section{Product Processing and Added Value}

Date production in Mexico is aimed at the export market of fresh fruits, and no commercial products derived from its processing are in the wide market yet. However, there is active development of new products that can be found in limited quantities in farm markets, state fairs and high-end stores. Artisanal production of alcoholic beverages such as liquors, wines and beers is very common. Confectionery products of dates filled and/or covered with chocolate, pecans, coconut, or pistachios are available. Date breads, pies, cakes, and cookies are often found in bakery shops. A great contribution to the Mexican gastronomy is the date tamale, consisting of a mixture of corn dough with date paste, in an envelope of corn husks, that is cooked by steaming. Interesting proposals of date-chile pepper dressings begin to be mentioned. The date milkshake may be the most common way of consuming dates, after eating them fresh. A coffee substitute from toasted date seeds is starting to appear, as well as facial beauty treatments based on the antioxidants and nutrient content of the seed. Candy pieces of date paste in a mixture with chile pepper are appreciated by young people. Interestingly, dates that do not meet the quality standards for the fresh market are used in the elaboration of the products, giving better economic returns to the growers, sometimes more than the first quality dates. Recently, an organic date sugar product can now be found in some large chain markets. 


\section{Conclusions and Recommendations}

The date growing industry has the potential to contribute to the economic development of the northwest of Mexico, since there are not many other regions in Mexico that can grow high quality dates. Date growers are improving date cultural practices, and it is very possible that yields increase from the current average of 7.9 ton/ha to 10 ton/ha in the next 5 years. Consistent support from the Ministry of Agriculture of Mexico (formerly SAGARPA, now SADER), during the last 35 years, supported an increase in date production of $600 \%$. Since it is a recently introduced crop and is commercially grown only in the northwest region of the country, it is necessary to create a technological package for this crop in order to define good agricultural practices. The main obstacle for this industry is commercialization and export. Currently, there is only one integrated company that exports the packaged fruit to other countries. Training and financing are required so that small and medium producers are better organized and form co-ops for packing and marketing of their products. They will also need to explore new export options in the international markets.

In order to stimulate internal consumption, it is necessary to widely disseminate the great health benefits generated by the consumption of this fruit. Events such as the celebrated Date Route in San Luis Rio Colorado, Sonora, and the Date Fair in the Ejido Jalapa, in the valley of Mexicali, Baja California in 2018, stimulate knowledge of this fruit and its derivatives. It is necessary to carry out more research on date palms in order to improve the current methods of cultivation, to be prepared for possible future pests, work with practices to optimize the use of water, and develop new products derived from the date. Likewise, research to take advantage of date palm agricultural residues, such as the extraction of oil from the seed, or use as biofuel or livestock feed is needed. In general, the date cultivated in Mexico is appreciated for its high quality. Organic farming is a good option to obtain better date prices, but farmers worry about complying with all the requirements demanded by SADER authorities and certification companies.

Author Contributions: R.S.-T. and N.O.-U. conceived and designed the study, completed the fieldwork and wrote the paper; R.K. co-wrote the paper, and all authors contributed to its editing.

Funding: This research was funded by Programa para el Desarrollo Profesional Docente (PRODEP: Project 511-6/17-7559).

Acknowledgments: We are grateful to Rafael Quirarte-Gutiérrez and Roberto Torres-Yescas from Corporativo RUVA, Ramiro Quiroz-Gonzalez and Jesus Cordova-Murrieta from Palmeras RQ, and Juanita Martinez-Vieyra from Vieyra dates, for allowing us access to their plantations and for the facilities granted to carry out this study. Delia Dalila González-Machado and Carlos Zambrano-Reyes from SADER Baja California, and Jose Godinez-Placencia from SEDAGRO BC, for providing us with all the statistical, economic and production data of date in Mexico. Antonio Morales-Maza and Cristobal Navarro-Ainza from INIFAP for sharing with us their experience about this crop.

Conflicts of Interest: The authors declare no conflict of interests.

\section{References}

1. Abdelouauhhab, Z.; Arias-Jimenez, E.J. Date Palm Cultivation, 1st ed.; Food and Agricultural Organization of the United Nations: Rome, Italy, 1999; ISBN 92-5-1-104863-0.

2. Chao, C.T.; Krueger, R.R. The date palm (Phoenix dactylifera L.): Overview of biology, uses, and cultivation. HortScience 2007, 42, 1077-1082. [CrossRef]

3. Al-Yahyai, R.; Manickavasagan, A. An Overview of Date Palm. In Dates Production, Processing, Food and Medicinal Values; Manickavasagan, A., Mohamed, E.M., Sukumar, E., Eds.; CRC Press: Florida, FL, USA, 2012; pp. 3-11. ISBN 9781439849477.

4. Nixon, R.W. The date palm—“Tree of Life”in the subtropical deserts. Econ. Bot. 1951, 5, 274-301. [CrossRef]

5. Rivera, D.; Johnson, D.; Delgadillo, J.; Carrillo, M.H.; Obón, C.; Krueger, R.; Alcaraz, F.; Ríos, S.; Carreño, E. Historical evidence of the Spanish introduction of date palm (Phoenix dactylifera L., Arecaceae) into the Americas. Genet. Resour. Crop. Evolut. 2013, 60, 1433-1452. [CrossRef] 
6. Salomón-Torres, R.; Ortiz-Uribe, N.; Sol-Uribe, J.A.; Villa-Angulo, C.; Villa-Angulo, R.; Valdez-Salas, B.; García-González, C.; Iñiguez Monroy, C.G.; Norzagaray-Plasencia, S. Influence of different sources of pollen on the chemical composition of date (Phoenix dactylifera L.) cultivar Medjool in México. Aust. J. Crop. Sci. 2018, 12. [CrossRef]

7. Salomon-Torres, R.; Ortiz-Uribe, N.; Villa-Angulo, R.; Villa-Angulo, C.; Norzagaray-Plasencia, S.; Garcia-Verdugo, C. Effect of Pollenizers on Production and Fruit Characteristics of Date Palm (Phoenix dactylifera L.) Cultivar Medjool en Mexico. Turk. J. Agri. For. 2017, 41.

8. FAO. Food and Agriculture Organization of the United Nations. Available online: http://www.fao.org/ faostat/en/\#data/QC (accessed on 1 August 2018).

9. Salomón-Torres, R.; Ortiz-Uribe, N.; Villa-Angulo, R. La Produccion de la Palma Datilera (Phoenix dactylifera L.) en México. Rev. UABC 2017, 15-20. (In Spanish)

10. Arias, E. Promoción de la producción y mejoramiento de dátiles; Rome, Italy, 2008. (In Spanish)

11. Arias, E.; Hodder, A.J.; Oihabi, A. FAO support to date palm development around the world: 70 years of activity. Emir. J. Food Agric. 2016, 28, 1-11.

12. SIAP. Servicio de Informacion Agroalimentaria y Pesquera. Available online: https://nube.siap.gob.mx/ cierreagricola/ (accessed on 18 July 2018). (In Spanish)

13. Aschmann, H. The introduction of date palms into Baja California. Econ. Bot. 1957, 11, 174-177. [CrossRef]

14. De Grenade, R. Date palm as a keystone species in Baja California peninsula, Mexico oases. J. Arid Environ. 2013, 94, 59-67. [CrossRef]

15. De Grenade, R.; Nabhan, G.P.; Cariño Olvera, M. Oases of the Baja California peninsula as sacred spaces of agrobiodiversity persistence. Agri. Human Values 2016, 94, 455-474. [CrossRef]

16. Johnson, D.V.; Al-khayri, J.M.; Jain, M.S. Introduction: Date Production Status and Prospects in Africa and the Americas. In Date Palm Genetic Resources and Utilization: Africa and the Americas; Springer: New York, NY, USA, 2015; pp. 3-18.

17. Elhoumaizi, M.A.; Devanand, P.S.; Fang, J.; Chao, C.-C.T. Confirmation of “Medjool” Date as a Landrace Variety through Genetic Analysis of "Medjool" Accessions in Morocco. J. Am. Soc. Hortic. Sci. 2006, 131, 403-407. [CrossRef]

18. Rahnama, A.A.; Rahkhodaei, E. The effects of date pollinizer variety and pollination time on fruit set and yield of Medjhol date palm. J. Adv. Agri. 2014, 2, 67-71. [CrossRef]

19. Fresh Plaza. Israeli Medjool dates dominate the global market. Available online: https://www.freshplaza. com/article/155227 / Israeli-Medjool-dates-dominate-the-global-market/ (accessed on 20 September 2018).

20. INIFAP. Instituto Nacional de Investigaciones Agrícolas, Pecuarias y Forestales. Available online: https: / /www.gob.mx/inifap (accessed on 9 September 2018).

21. UES. Universidad Estatal de Sonora. Available online: https://www.ues.mx/ (accessed on 9 September 2018).

22. Salomon-Torres, R.; Ortiz-Uribe, N.; Villa-Angulo, C.; Villa-Angulo, R.; Yaurima-Basaldúa, V.H. Assessment SSR Markers Used in Analysis of Genetic Diversity of Date Palm (Phoenix dactylifera L.). Plant. Cell. Biotechnol. Mol. Biol. 2017, 18, 269-280.

23. Hodel, D.R.; Marika, M.A.; Ohara, L.M. The South American Palm Weevil A New Threat to Palms in California and the Southwest. PalmArbor 2016, 3, 27.

24. Tinajero, R.; Rodríguez-Estrella, R. Cotorra argentina (Myiopsitta monachus), especie anidando con éxito en el sur de la Península de Baja California. Mex. Zool. Act. 2015, 31, 190-197. (In Spanish) [CrossRef]

25. The Guardian News. Mexico protesters fear US-owned brewery will drain their land dry. Available online: https:/ / www.theguardian.com/world/2018/feb/04/mexico-water-brewery-mexicaliconstellation-brands (accessed on 8 August 2018).

26. Televisa News. Planta cervecera genera conflicto en Mexicali, por desabasto de agua. Available online: https: / / noticieros.televisa.com/ultimas-noticias/planta-cervecera-genera-conflicto-mexicali-desabasto-agua/ (accessed on 8 August 2018). (In Spanish)

27. U.S. Deparment of the Interior Bureau of Reclamation: Lower Colorado Region-Law of the River. Available online: https:/ / www.usbr.gov/lc/region/g1000/lawofrvr.html (accessed on 18 December 2018).

28. Wright, G.C. The Commercial Date Industry in the United States and Mexico. HortScience 2016, 51, 1333-1338. [CrossRef]

29. Morales-Maza, A.; Payan-Ochoa, S.; Jaime-Garcia, N.; Quevedo-Aguilar, I. Enraizado de Hijuelos de Palma Datilera (Phoenix Dactylifera L.); Mexicali, Mexico, 2016. (In Spanish) 
30. Angulo-Zuñiga, Q.; Cota-García, J.A.; Aguirre-Avendaño, N.O. Compendio de la Palma Datilera, 1st ed.; Laredo Impresores: Mexicali, Mexico, 2015; ISBN 978-607-7951-41-4. (In Spanish)

31. UABCS. Universidad Autonoma de Baja California Sur. Available online: https://www.uabcs.mx/ (accessed on 9 September 2018).

32. Bouhlali, E.; dine, T.; Ramchoun, M.; Alem, C.; Ghafoor, K.; Ennassir, J.; Zegzouti, Y.F. Functional composition and antioxidant activities of eight Moroccan date fruit varieties (Phoenix dactylifera L.). J. Saudi. Soc. Agri. Sci. 2017, 16, 257-264. [CrossRef]

33. Bouhlali, T.; Alem, C.; Ennassir, J.; Benlyas, M.; Nait, A.; Filali, Y. Phytochemical compositions and antioxidant capacity of three date (Phoenix dactylifera L.) seeds varieties grown in the South East Morocco. J. Saudi Soc. Agri. Sci. 2017, 16, 350-357. [CrossRef]

34. Vinita, V.; Punia, D. Nutritional composition of fruit of four date palm (Phoenix dactylifera L.) cultivars grown in Haryana, India. Asian J. Dairy Food Res. 2016, 35, 331-334. [CrossRef]

35. Ghnaim, H.D.; Al-Muhtaseb, J.A. Effect of Pollen Source on Yield, Quality and Maturity of "Mejhool" Date Palm. Jordan J. Agri. Sci. 2006, 2, 8-15.

36. SEDAGRO. Secretaria de Desarrollo Agrario. Available online: http://www.sefoa.gob.mx/ (accessed on 20 September 2018).

(c) 2019 by the authors. Licensee MDPI, Basel, Switzerland. This article is an open access article distributed under the terms and conditions of the Creative Commons Attribution (CC BY) license (http:/ / creativecommons.org/licenses/by/4.0/). 